\title{
PENERAPAN MODEL PEMBELAJARAN KOOPERATIF TIPE MAKE A MATCH UNTUK MENINGKATKAN HASIL BELAJAR SISWA PADA PEMBELAJARAN TEMATIK KELAS III-A UPT. DI SD NEGERI O1 LIMO KAUM
}

\section{TARUDDIN}

taruddin01@gmail.com

\begin{abstract}
This study aims to improve student learning outcomes by applying the make a match cooperative learning model on the theme of Energy and Change in class III-A UPT. at SD Negeri 01 Limo Kaum. This type of research is a classroom action research (PTK) which is carried out in two cycles. The subjects of this study were students of class III-A UPT. in SD Negeri 01 Limo Kaum, amounting to 20 students. Data collection techniques used were observation, interviews, tests and documentation. The data obtained are in the form of observations as primary data, and learning outcomes tests as supporting data. The data analysis technique used is descriptive quantitative and qualitative. The results of this study indicate that the application of the cooperative learning model type make a match in thematic learning in class III-A UPT. at SD Negeri 01 Limo Kaum. From the data, the average student learning evaluation results increased, namely from the pre-cycle of 67.5 in the very poor category, increasing to 76.5 in the sufficient category in the first cycle, and increasing again to 85 with the very good category in the second cycle. This cycle stage states that student learning outcomes can increase due to applying the cooperative learning model make a match type.
\end{abstract}

Keywords: Cooperative learning model type Make A Match, Learning Outcomes.

Abstrak: Penelitian ini bertujuan untuk meningkatkan hasil belajar siswa dengan menerapkan model pembelajaran kooperatif tipe make a match pada tema Energi dan Perubahannya di kelas III-A UPT. di SD Negeri 01 Limo Kaum. Jenis penelitian yang dilakukan adalah penelitian tindakan kelas (PTK) yang dilaksanakan dalam dua siklus. Subjek penelitian ini adalah siswa kelas III-A UPT. di SD Negeri 01 Limo Kaum yang berjumlah 20 siswa. teknik pengumpulan data yang digunakan adalah observasi, wawancara, tes dan dokumentasi. Data yang diperoleh berupa hasil observasi sebagai data primer, serta tes hasil belajar sebagai data pendukung. Teknik analisis data yang digunakan adalah deskriptif kuantitatif dan kualitatif. Hasil penelitian ini menunjukkan bahwa penerapan model pembelajaran kooperatif tipe make a match pada pembelajaran tematik di kelas III-A UPT. di SD Negeri 01 Limo Kaum. Dari data rata-rata hasil evaluasi belajar siswa meningkat, yaitu dari pra siklus sebesar 67,5 dengan kategori sangat kurang,meningkat menjadi 76,5 dengan kategori cukup pada siklus I, dan meningkat lagi menjadi 85 dengan kategori sangat baik pada siklus II. Tahapan siklus ini menyatakan bahwa hasil belajar siswa dapat meningkat dikarenakan menerapkan model pembelajaran kooperatif tipe make a match.

Kata Kunci: Model pembelajaran kooperatif tipe Make A Match, Hasil Belajar.

\section{A. Pendahuluan}

Pendidikan merupakan usaha sadar dan terencana untuk mewujudkan suasana belajar dan proses pembelajaran agar peserta didik secara aktif mengembangkan potensi dirinya untuk memiliki kekuatan spiritiual keagamaan, pengendalian diri 
kepribadian, kecerdasan, akhlak mulia, serta keterampilan yang diperlukan dirinya, masyarakat, bangsa, dan negara. Pendidikan adalah segala pengalaman belajar yang berlangsung dalam segala lingkungan dan sepanjang hidup. Sedangkan pengertian belajar adalah perubahan disposisi atau kemampuan yang dicapai seseorang melalui aktivitas (Agus Suprijono, 2009, hal 2). Pendidikan juga merupakan suatu perubahan perilaku manusia dari tidak tahu menjadi tahu dan bertujuan untuk menjadikan peradaban bangsa yang bermartabat dalam rangka mencerdaskan kehidupan bangsa. Pendidikan merupakan hal yang penting dan memerlukan perhatian yang serius.

Banyak kritikan dari praktis pendidikan, akademisi dan masyarakat yang sering dilontarkan kepada sistem pendidikan. Kritikan tersebut sangat komplek, di mulai dari sistem pendidikan yang berubah-ubah ketika ganti menteri pendidikan, kurikulum yang kurang tepat dengan mata pelajaran yang terlalu banyak dan tidak berfokus pada hal-hal yang seharusnya diberikan, dan lain sebagainya. Namun demikian, masalah sering menjadi perhatian setiap sistem pendidikan yakni problem penilaian hasil belajar yang kurang efektif. Hal tersebut terjadi dikarenakan adanya perubahan kurikulum dari KTSP menjadi kurikulum 2013 yang lebih dikenal dengan pembelajaran tematik. Tujuan pendidikan adalah mengembangkan potensi peserta didik agar menjadi manusia yang beriman, bertakwa kepada Tuhan, berakhlak mulia, cakap, kreatif, mandiri, dan menjadi manusia yang bertanggung jawab. Manusia itu sendiri adalah pribadi yang utuh dan pribadi yang kompleks sehingga sulit untuk dipahami secara tuntas. Dalam pandangan islam karakter itu sama dengan akhlak. Para Nabi diutus Allah untuk menyempurnakan akhlak manusia. Akhlak atau karakter menjadi penanda bahwa seseorang itu layak atau tidak layak disebut manusia. Kelaknya inilah tugas pendidikan yaitu membantu manusia menjadi manusia (Abdul Majid dan Dian Andayani, hal 4). Dalam proses pendidikan yang ada di sekolah, kegiatan belajar merupakan kegiatan yang paling pokok. Berhasil atau tidaknya pencapaian tujuan pendidikan tergantung pada bagaimana proses belajar yang dialami oleh siswa. dalam kegiatan belajar guru sebagai sentral pendidikan, berarti guru dituntut mampu menyalurkan ilmunya terhadap peserta didik melalui kegiatan pembelajaran.

Saat ini, sedang gencar-gencarnya para praktisi di bidang pendidikan membicarakan mengenai kurikulum 2013. Kemunculan kurikulum 2013 diharapkan mampu mencetak generasi yang bukan hanya handal dalam hal akademik namun juga memiliki sikap atau etika serta moral yang baik. Jika dibandingkan dengan kurikulum sebelumnya, yakni KTSP. Kurikulum 2013 lebih menekankan pada sisi afektif sebagai cara untuk mencapai suatu tujuan kurikulum itu sendiri. Sesuai dengan kurikulum yang diterapkan saat ini adalah Kurikulum 2013, ataupun sering disebut pembelajaran tematik. Terutama di jenjang pendidikan Sekolah Dasar (SD) atau Madrasah Ibtidaiyah (MI) pembelajaran tematik sudah mulai diterapkan. Pembelajaran tematik merupakan pembelajaran terpadu yang menggunakan tema untuk mengaitkan beberapa mata pelajaran sehingga dapat memberikan pengalaman bermakna kepada siswa. Dengan pengertian lain pembelajaran tematik merupakan sejumlah konsep mata pelajaran yang dikaitkan, dihubungkan, dan dipadukan menjadi satu untuk membentuk suatu tema dengan maksud untuk merangsang pengetahuan dan keterampilan siswa dalam pembelajaran.

Pembelajaran tematik adalah suatu wahana dimana pembelajaran yang diharapkan harus tumbuh dan berkembang sesuai lingkungan diri siswa. pembelajaran tematik ini menuntut siswa untuk aktif dalam berlangsungnya pembelajaran, baik itu dari pengalamannya dalam berlatih, berfikir, melakukan kegiatan, sehingga daya 
berfikir dan keterampilan siswa lebih terlatih. Namun kenyataannya, dalam proses pembelajaran tematik ini masih sulit dan tidak menarik untuk diterapkan. Pembelajaran masih belum melibatkan siswa, oleh itulah siswa masih kurang aktif sehingga hasil belajar siswa menjadi rendah. Siswa hanya menerima materi dari guru, siswa hanya mendengarkan penjelasan materi dari guru dan materi yang diberikan hanya dihafalkan saja. Siswa tidak diarahkan mencari pengetahuan sendiri tentang hal - hal baru terlebih dahulu, hal inilah yang menyebabkan pembelajaran tidak menarik, pembelajaran yang monoton sehingga siswa tidak antusias dalam pembelajaran, dikarenakan menghafal siswa jadi sering cepat lupa dengan materi yang telah diberikan.

Berdasarkan observasi yang dilakukan peneliti di kelas III-A di UPT. SD Negeri 01 Limo Kaum Kecamatan Limo Kaum Kabupaten Tanah Datar, rendahnya hasil belajar siswa tersebut terlihat dari hasil yang diperoleh siswa yang kurang maksimal. Siswa yang tuntas sesuai dengan KKM hanya $45 \%$ dan yang belum tuntas sesuai KKM 55\% dengan KKM yang ditentukan yaitu 78. Proses belajar yang masih dilakukan secara konvensional, dimana guru lebih banyak menerangkan materi pembelajaran dan siswa hanya berperan sebagai penyimak. Penyebab lainnya bisa dikarenakan kurangnya keaktifan siswa dalam mengerjakan soal-soal yang diberikan guru, disamping itu cara mengajar kurang kreatif sehingga anak kurang termotivasi dalam belajar. Kesulitan belajar siswa ditimbulkan bukan semata - mata materi saja yang sangat sulit tetapi bisa disebabkan cara mengajar guru yang kurang efektif. Proses pembelajaran yang efektif membawa pencapaian hasil belajar yang maksimal. Salah satu pendekatan dalam proses pembelajaran inovatif yaitu pembelajaran kooperatif. Dalam pembelajaran kooperatif memiliki beberapa tipe, di antaranya adalah Make A Match yang mana tipe pembelajaran ini sangat menyenangkan dan membangun semangat siswa dalam proses pembelajaran sehingga dapat meningkatkan hasil belajar siswa.

Berdasarkan fenomena diatas peneliti mencoba untuk mengangkat masalah ini dan menuangkannya dalam sebuah Penelitian Tindakan Kelas (PTK) yang berjudul "Penerapan Model Pembelajaran Kooperatif Tipe Make A Match untuk Meningkatkan Hasil Belajar Siswa pada Pembelajaran Tematik Kelas III-A UPT. di SD Negeri 01 Limo Kaum". Untuk menghindari luasnya masalah yang dikaji, maka peneliti memberikan fokus penelitian sebagai berikut: 1) Penelitian ini difokuskan di kelas IIIA UPT. SD Negeri 01 Limo Kaum; 2) Penelitian ini difokuskan pada Tema 6 Energi dan Perubahannya, Subtema 1 Sumber Energi; 3) Penelitian ini menerapkan model pembelajaran kooperatif tipe Make A Match untuk meningkatkan hasil belajar; dan 4) Subjek penelitian adalah guru kelas dan siswa kelas III-A di UPT. SD Negeri 01 Limo Kaum.

\section{B. Metodologi Penelitian}

Subjek penelitian adalah guru dan siswa kelas III-A UPT. SD Negeri 01 Limo Kaum dengan jumlah siswa 20 orang, terdiri dari 9 orang siswa laki-laki 12 orang siswa perempuan. Penelitian ini dilaksanakan di kelas III-A UPT. SD Negeri 01 Limo Kaum, alasan praktis pemilihan lokasi tersebut juga didasarkan karena keterjangkauan lokasi penelitian oleh peneliti baik dari segi tenaga maupun efesien waktu dan peneliti sebagai pengajar disekolah tersebut. Rancangan tindakan yang digunakan penelitian ini merupakan Penelitian Tindakan Kelas (PTK), ruang lingkupnya adalah pembelajaran di dalam kelas yang dilaksanakan oleh guru dan siswa untuk melakukan 
perbaikan dan berdampak pada peningkatan belajar peserta didik. (IGAK Wardani, 2008, hal 24). Penelitian tindakan kelas ini bercirikan adanya perubahan yang secara terus menerus. Apabila pembelajaran membaca pemahaman dengan metode pemberian tugas belum dapat meningkatkan kemampuan membaca pemahaman pada siklus pertama, peneliti merencanakan tindakan siklus kedua dan seterusnya sampai mencapai hasil yang diharapkan. Dengan demikian, jumlah siklus tidak terikat dan tidak ditentukan sampai siklus tertentu. Teknik pengumpulan data merupakan langkah yang paling utama dalam penelitian, karena tujuan utama dari penelitian adalah mendapatkan data. Data yang valid dan lengkap sangat menentukan kualitas penelitian. Dalam penelitian ini, peneliti menggunakan teknik observasi, tes dan dokumentasi. Analisis data adalah proses mencari dan menyusun secara sistematis data yang diperoleh dari hasil wawancara, catatan lapangan, dan dokumentasi, dengan cara mengorganisasikan data ke dalam kategori, menjabarkan ke dalam unit-unit, melakukan sintesa, menyusun kedalam pola, memilih mana yang penting dan yang akan dipelajari, dan membuat kesimpulan sehingga mudah dipahami oleh diri sendiri maupun orang lain. Data yang diperoleh dalam PTK, secara umum dianalisis melalui deskriptif kualitatif. Analisis data dilakukan pada tiap data yang dikumpulkan, baik data kuantitatif maupun data kualitatif. Data kualitatif dianalisis dengan menggunakan cara kuantitatif sederhana, yakni dengan persentase (\%), dan data kualitatif dianalisis dengan membuat penilaianpenilaian kualitatif (kategori) (Paizaluddin dan Ermalinda, 2016, hal. 135).

\section{Hasil dan Pembahasan}

\section{Deskripsi Kondisi Awal Hasil Belajar Siswa}

Kondisi awal merupakan kondisi siswa sebelum dilaksanakannya pembelajaran Kooperatif Tipe Make A Match. Kemudian dinilai dan diperoleh hasil prosesntase ketuntasan seperti tertuang pada tabel berikut.

Tabel Kondisi Awal Hasil Belajar Siswa/Pra Siklus

\begin{tabular}{|l|l|l|l|l|l|l|}
\hline \multicolumn{7}{|c|}{ Tabel Kondisi Awal Hasil Belajar.Siswa/Pra Siklus. } \\
\hline No & Nama Siswa & KKM & Nilai & Tuntas & Tidak Tuntas \\
\hline 1 & Alfarezel Bahry. AG & 78 & 40 & & $\sqrt{ }$ \\
\hline 2 & Alvin Qodri Khoyri & 78 & 70 & & $\sqrt{ }$ \\
\hline 3 & Aqeef Daffa.AG & 78 & 80 & $\sqrt{ }$ & \\
\hline 4 & Ayra Putri.R & 78 & 60 & & $\sqrt{ }$ \\
\hline 5 & FayzaHaura Anaya & 78 & 90 & $\sqrt{ }$ & \\
\hline 6 & Hafidzalatul Rohmah & 78 & 80 & $\sqrt{ }$ & \\
\hline 7 & Hanifah Faizah.A & 78 & 50 & & $\sqrt{ }$ \\
\hline 8 & Inayatul Hasanah & 78 & 60 & & $\sqrt{ }$ \\
\hline 9 & M. Galangerlangga & 78 & 80 & $\sqrt{ }$ & \\
\hline 10 & M. Nabil Arista & 78 & 40 & & $\sqrt{ }$ \\
\hline 11 & Mahrin Safa.Q & 78 & 80 & $\sqrt{ }$ & \\
\hline 12 & Melvin Pratama.D & 78 & 70 & & $\sqrt{ }$ \\
\hline 13 & Mumtazah Ulya.B & 78 & 80 & $\sqrt{ }$ & \\
\hline 14 & Nazhifa Arafah.K & 78 & 70 & & $\sqrt{ }$ \\
\hline 15 & Nicholas Prayata.R & 78 & 80 & $\sqrt{ }$ & \\
\hline 16 & Nur Rahma Assyfa & 78 & 60 & & $\sqrt{ }$ \\
\hline 17 & Ratu Zahra Amra & 78 & 60 & & $\sqrt{ }$ \\
\hline 18 & Riva Wilisa Putri & 78 & 80 & $\sqrt{ }$ & \\
\hline 19 & Syafa Ramadhani & 78 & 80 & $\sqrt{ }$ & \\
\hline 20 & Ahmad Yazeed. R & 78 & 40 & & $\sqrt{ }$ \\
\hline Jumlah & \multicolumn{3}{|l|}{1350} & 9 & 11 \\
\hline Nilai rata-rata & 67,5 & & $55 \%$ \\
\hline Persentase. & & $45 \%$ & \\
\hline
\end{tabular}


Dari tabel diatas terlihat bahwa hasil belajar siswa masih rendah. Karena siswa yang tuntas dalam belajar hanya 9 orang siswa atau hanya 45\%, sedangkan jumlah siswa yang tidak tuntas dalam belajar berjumlah 11 orang siswa atau sekitar 55\%, selain itu nilai rata-rata siswa 67,5 sedangkan KKM yang telah ditentukan oleh guru adalah 78 artinya tingkat ketuntasan dalam belajar siswa masih rendah dari yang seharusnya yaitu 78. Dari hasil yang diperoleh diatas, peneliti mulai melakukan penelitian tindakan kelas dengan melakukan penerapan Model Pembelajaran Kooperatif tipe Make A Match guna meningkatkan hasil belajar siswa pada Mata Pelajaran Tematik di kelas III-A UPT. di SD Negeri 01 Limo Kaum.

\section{Deskripsi Hasil Penelitian Siklus I}

Pelaksanaan siklus I dilakukan selama 2 kali pertemuan dalam pelaksanaan siklus I kegiatan yang dilakukan meliputi perencanaan, pelaksanaan, observasi, dan refleksi.Untuk melihat seberapa besar peningkatan hasil belajar dan pemahaman siswa terhadap materi yang telah diajarkan. Pada siklus pertama ini dilaksanakan tes formatif 1 yang terdiri dari soal pilihan ganda.

Tabel Hasil Belajar siswa Pada Siklus I

\begin{tabular}{|l|l|l|l|l|l|}
\hline No & Nama Siswa & KKM & Nilai & Tuntas & Tidak Tuntas \\
\hline 1 & Alfarezel Bahry.AG & 78 & 60 & & $\sqrt{ }$ \\
\hline 2 & Alvin Qodri Khoyri & 78 & 80 & $\sqrt{ }$ & \\
\hline 3 & Ageef Daffa.AG & 78 & 80 & $\sqrt{ }$ & \\
\hline 4 & Ayra Putri.R & 78 & 70 & & $\sqrt{ }$ \\
\hline 5 & FayzaHaura Anaya & 78 & 100 & $\sqrt{ }$ & \\
\hline 6 & Hafidzalatul Rohmah & 78 & 90 & $\sqrt{ }$ & \\
\hline 7 & Hanifah Faizah.A & 78 & 60 & & $\sqrt{ }$ \\
\hline 8 & Inayatul Hasanah & 78 & 70 & & $\sqrt{ }$ \\
\hline 9 & M. Galangerlangga & 78 & 90 & $\sqrt{ }$ & \\
\hline 10 & M. Nabil Arista & 78 & 40 & & \\
\hline 11 & Mahrin Safa.Q & 78 & 80 & $\sqrt{ }$ & \\
\hline 12 & Melvin Pratama.D & 78 & 80 & $\sqrt{ }$ & \\
\hline 13 & Mumtazah Ulya.B & 78 & 80 & $\sqrt{ }$ & \\
\hline 14 & Nazhifa Arafah.K & 78 & 80 & $\sqrt{ }$ & \\
\hline 15 & Nicholas Prayata.R & 78 & 90 & $\sqrt{ }$ & \\
\hline 16 & Nur Rahma Assyfa & 78 & 70 & & $\sqrt{ }$ \\
\hline 17 & Ratu Zahra Amra & 78 & 80 & $\sqrt{ }$ & \\
\hline 18 & Riva Wilisa Putri & 78 & 80 & $\sqrt{ }$ & \\
\hline 19 & Syafa Ramadhani & 78 & 100 & $\sqrt{ }$ & \\
\hline 20 & Ahmad Yazeed. R & 78 & 50 & & $\sqrt{ }$ \\
\hline Jumlah & & 1530 & 13 & 7 \\
\hline Nilai rata-rata & 76,5 & & \\
\hline Persentase. & & $65 \%$ & \\
\hline 1 & & & & \\
\hline
\end{tabular}

Hasil dari tabel diatas diketahui bahwa nilai rata-rata siswa masih rendah dan belum memenuhi Kriteria Keberhasilan Minimal (KKM). Hal ini terlihat dari rendahnya nilai rata-rata yang diperoleh siswa pada siklus I yaitu 76,5 jumlah siswa yang memperoleh nilai yang $\geq 78$ hanya 13 orang atau $65 \%$ dari jumlah siswa yang memperoleh nilai dan siswa yang belum berhasil sebanyak 7 orang atau 35\% dari jumlah siswa keseluruhan, artinya tindakan yang diberikan pada siklus I belum mencapai Indikator keberhasilan tindakan Siswa pada kelas III-A di UPT. SD Negeri 01 Limo Kaum Kecamatan Limo Kaum Kabupaten Tanah Datar, oleh karena itu tindakan harus dilanjutkan pada siklus II. 


\section{Deskripsi Hasil Penelitian Siklus II}

Pelaksanaan siklus II dilakukan selama 2 kali pertemuan. Untuk melihat seberapa besar peningkatan hasil belajar dan pemahaman siswa terhadap materi yang telah diajarkan. Pada siklus kedua ini dilaksanakan tes formatif dua yang terdiri dari soal pilihan ganda.

Tabel Hasil Belajar siswa Pada Siklus II

\begin{tabular}{|l|l|l|l|l|l|}
\hline No & Nama Siswa & KKM & Nilai & Tuntas & Tidak Tuntas \\
\hline 1 & Alfarezel Bahry. AG & 78 & 80 & $\sqrt{ }$ & \\
\hline 2 & Alvin Qodri Khoyri & 78 & 100 & $\sqrt{ }$ & \\
\hline 3 & Aqeef Daffa.AG & 78 & 80 & $\sqrt{ }$ & \\
\hline 4 & Ayra Putri.R & 78 & 80 & $\sqrt{ }$ & \\
\hline 5 & FayzaHaura Anaya & 78 & 100 & $\sqrt{ }$ & \\
\hline 6 & Hafidzalatul Rohmah & 78 & 100 & $\sqrt{ }$ & \\
\hline 7 & Hanifah Faizah.A & 78 & 80 & $\sqrt{ }$ & \\
\hline 8 & Inayatul Hasanah & 78 & 80 & $\sqrt{ }$ & \\
\hline 9 & M. Galangerlangga & 78 & 100 & $\sqrt{ }$ & \\
\hline 10 & M. Nabil Arista & 78 & 50 & & $\sqrt{ }$ \\
\hline 11 & Mahrin Safa.Q & 78 & 90 & $\sqrt{ }$ & \\
\hline 12 & Melvin Pratama.D & 78 & 80 & $\sqrt{ }$ & \\
\hline 13 & Mumtazah Ulya.B & 78 & 80 & $\sqrt{ }$ & \\
\hline 14 & Nazhifa Arafah.K & 78 & 80 & $\sqrt{ }$ & \\
\hline 15 & Nicholas Prayata.R & 78 & 100 & $\sqrt{ }$ & \\
\hline 16 & Nur Rahma Assyfa & 78 & 80 & $\sqrt{ }$ & \\
\hline 17 & Ratu Zahra Amra & 78 & 90 & $\sqrt{ }$ & \\
\hline 18 & Riva Wilisa Putri & 78 & 80 & $\sqrt{ }$ & \\
\hline 19 & Syafa Ramadhani & 78 & 100 & $\sqrt{ }$ & \\
\hline 20 & Ahmad Yazeed. R & 78 & 70 & & $\sqrt{ }$ \\
\hline Jumlah & & 1700 & 18 & 2 \\
\hline Nilai rata-rata & 85 & & \\
\hline Persentase & & $90 \%$ & $10 \%$ \\
\hline & & & & \\
\hline
\end{tabular}

Hasil dari tabel diatas diketahui bahwa nilai rata-rata siswa masih rendah dan belum memenuhi Kriteria Keberhasilan Minimal (KKM). Hal ini terlihat dari rendahnya nilai rata-rata yang diperoleh siswa pada siklus I yaitu 76,5 jumlah siswa yang memperoleh nilai yang $\geq 78$ hanya 13 orang atau $65 \%$ dari jumlah siswa yang memperoleh nilai dan siswa yang belum berhasil sebanyak 7 orang atau 35\% dari jumlah siswa keseluruhan, artinya tindakan yang diberikan pada siklus I belum mencapai Indikator keberhasilan tindakan Siswa pada kelas III-A di UPT. SD Negeri 01 Limo Kaum Kecamatan Limo Kaum Kabupaten Tanah Datar, oleh karena itu tindakan harus dilanjutkan pada siklus II. Diatas dapat kita lihat bahwa hasil belajar siswa pada siklus II sudah mengalami penigkatan. Ini dapat diketahui dari siklus I yang diikuti 20 orang siswa, nilai rata-rata yang diperoleh siswa meningkat dari 76,5 pada siklus I menjadi 85 pada siklus II. Siswa yang memperoleh nilai $\geq 78$ sebanyak 18 orang siswa, itu berarti keberhasilan siswa mencapai $90 \%$ siswa yang belum berhasil 2 orang siswa atau 10\%. Angka ini telah menunjukkan bahwa hasil belajar siswa pada kelas III-A di UPT. SD Negeri 01 Limo Kaum Kecamatan Limo Kaum Kabupaten Tanah Datar telah mencapai indikator keberhasilan tindakan siswa. oleh karena itu, penelitian ini tidak perlu dilanjutkan lagi.

\section{Pembahasan}

Penelitian ini merupakan penelitian tindakan kelas (PTK) yang bertujuan untuk meningkatkan hasil belajar siswa dengan menerapkan model pembelajaran kooperatif tipe make a match kelas III-A di UPT. SD Negeri 01 Limo Kaum. Kegiatan pembelajaran dengan menerapkan model pembelajaran kooperatif tipe make a match 
telah menunjukkan hasil yang efektif dalam pelaksanaan pembelajaran tematik kelas III-A di UPT. SD Negeri 01 Limo Kaum. Hal ini terlihat dari adanya peningkatan hasil belajar siswa yaitu dengan menerapkan model pembelajaran kooperatif tipe make a match karena dalam proses pembelajaran dengan menerapkannya pada siswa sedemikian rupa terlibat aktif dalam pembelajaran serta melatih pengetahuan siswa sehingga mampu memecahkan masalah yang dihadapi.

Data Hasil Observasi Aktivitas Belajar Siswa. Hasil yang diperoleh dari lembar observasi aktivitas belajar sswa digunakan peneliti dan guru sebagai acuan untuk melakukan perbaikan pada tahap pembelajaran selanjutnya. Hasil observasi yang diperoleh pada penelitian ini adalah sebagai berikut:

Tabel Perbandingan Hasil Observarsi Aktivitas Belajar Siswa dengan Menggunakan Model Pembelajaran Kooperatif Tipe Make A Match.

\begin{tabular}{|l|l|}
\hline Aktivitas Siswa & Persentase \\
\hline Siklus I & $67,3 \%$. \\
\hline Siklus II & $85,5 \%$. \\
\hline Peningkatan & $\mathbf{1 8 , 2 \%}$ \\
\hline
\end{tabular}

Sebagaimana tabel diatas, menunjukkan terjadinya peningkatan aktivitas belajar siswa dari siklus I ke siklus II.hal ini menunjukkan bahwa dengan penerapan model pembelajaran kooperatif tipe make a match dapat meningkatkan aktivitas belajar siswa kelas III-A di UPT. SD Negeri 01 Limo Kaum Kecamatan Limo Kaum Kabupaten Tanah Datar selama proses pembelajaran. Adapun persentase aktivitas siswa pada siklus I dan siklus II disajikan pada diagram berikut: Diagram 1 : Perbandingan Aktivitas Siswa

Data Hasil Observasi Aktivitas Guru. Hasil yang diperoleh dari lembar observasi aktivitas guru digunakan peneliti dan guru sebagai acuan untuk melakukan perbaikan pada tahap pembelajaran selanjutnya. Hasil observasi yang diperoleh pada penelitian ini adalah sebagai berikut:

Tabel Perbandingan Hasil Observarsi Aktivitas Guru dengan Menggunakan Model Pembelajaran Kooperatif Tipe Make A Match.

\begin{tabular}{|l|l|}
\hline Aktivitas Siswa & Persentase \\
\hline Siklus I & $73,3 \%$ \\
\hline Siklus II & $85,5 \%$. \\
\hline Peningkatan & $\mathbf{1 2 , 2 \%}$ \\
\hline
\end{tabular}

Sebagaimana ditunjukkan pada tabel terjadi peningkatan mengajar guru dari siklus I ke siklus II. Hal ini menunjukkan bahwa guru mengalami perbaikan dalam menciptakan kegiatan pembelajaran tematik dengan menerapkan model pembelajaran kooperatif tipe make a match sebagai upaya untuk meningkatkan hasil belajar siswa kelas III-A di UPT. SD Negeri 01 Limo Kaum Kecamatan Limo Kaum Kabupaten Tanah Datar. Adapun persentase aktivitas mengajar guru pada siklus I dan siklus II disajikan pada diagram berikut: Diagram Perbandingan Aktivitas Guru

Hasil Belajar Siswa. Untuk melihat seberapa besar peningkatan hasil belajar dan pemahaman siswa terhadap materi yang telah diajarkan. Pada siklus satu dan kedua ini dilaksanakan tes formatif dua yang terdiri dari soal pilihan ganda. 
Tabel Perbandingan Hasil Belajar Siswa dengan Menggunakan Model Pembelajaran Kooperatif Tipe Make A Match.

\begin{tabular}{|l|l|}
\hline Tes Akhir & Rata - rata \\
\hline Siklus I & $\mathbf{7 6 , 5}$ \\
\hline Siklus II & $\mathbf{8 5}$ \\
\hline Peningkatan & $\mathbf{8 , 5}$ \\
\hline
\end{tabular}

Sebagaimana tabel diatas, menunjukkan terjadinya peningkatan hasil belajar siswa dari siklus I ke siklus II.hal ini menunjukkan bahwa dengan penerapan model pembelajaran kooperatif tipe make a match dapat meningkatkan hasil belajar siswa kelas III-A di UPT. SD Negeri 01 Limo Kaum Kecamatan Limo Kaum Kabupaten Tanah Datar selama proses pembelajaran. Adapun peningkatan hasil belajar siswa pada siklus I dan siklus II disajikan pada diagram berikut. Diagram Perbandingan Hasil Belajar Siswa

\section{Penutup}

Proses pembelajaran yang baik dapat meningkatkan belajar yang baik pula. Untuk melaksanakan proses pembelajaran yang baik tersebut maka seorang guru harus memahami karakteristik siswa dengan demikian maka guru dapat mengambil tindakan yang tepat dan perbaikan-perbaikan terhadap kekurangan proses pembelajaran sehingga proses pembelajaran tersebut menjadi prioritas guru dalam mengatasi maslah yang ditemukan dalam kelas. Penelitian ini menerapkan model pembelajaran kooperatif tipe make a match dikarenakan model pembelajaran tersebut secara langsung memperlihatkan bentuk penerapannya kepada siswa sesuai materi pembelajaran dan siswa tidak hanya mendengarkan penjelasan dari guru saja. Berdasarkan hasil penelitian tindakan kelas (PTK) yang telah dilaksanakan mulai dari pra siklus, siklus I dan siklus II dapat disimpulkan bahwa pembelajaran dengan menerapkan model pembelajaran kooperatif tipe make a match pada pembelajaran tematik tema Energi dan Perubahannya dpat meningkatkan hasil belajar siswa. hal itu dapat disimpulkan dari rata-rata prasiklus adalah 67,5 dan persentase $45 \%$ dengan kategori kurang, dan setelah dilakukan tindakan siklus I hasil belajar siswa meningkat menjadi 76,5 dan persentase ketuntasannya adalah 65\% dengan kategori cukup dari jumlah keseluruhan siswa 20 orang diantaranya siswa yang tuntas berjumlah 13 orang dan yang tidak tuntas adalah 7 orang. Lalu meningkat dengan signifikan pada siklus II dengan rata-rata 85 dan persentase $90 \%$ dengn kategori sangat baik dari jumlah keseluruhan siswa 20 orang diantaranya siswa yang tuntas berjumlah 28 siswa dan yang tidak tuntas adalah 2 orang.

Berdasarkan analisis tes siklus I dan siklus II, kemampuan kognitif siswa kelas III-A di UPT. SD Negeri 01 Limo Kaum mengalami peningkatan pada setiap indikatornya. Sehingga dapat disimpulkan bahwa penerapan model pembelajaran kooperatif tipe make a match pada pembelajaran tematik dapat meningkatkan hasil belajar kognitif siswa kelas III-A di UPT. SD Negeri 01 Limo Kaum Kecamatan Limo Kaum Kabupaten Tanah Datar.

\section{Daftar Pustaka}

Abdul Majid \& Dian Andayani.2004. Pendidikan Agama Islam Berbasis Kompetensi Konsep dan Implementasi Kurikulum 2004. Bandung: PT Remaja Rosdakarya. 
Anis Setyowati. 2009. Upaya Meningkatkan Kecerdasan Verbal Linguistik Anak Melalui Membaca. Surakarta: UMS.

Akbar, P.S., \& Usman. 2008. Pengantar Statistika. Jakarta: Bumi Aksara.

Arikunto Suharsimi, Suhardjono, Supardi. 2012. Penelitian Tindakan Kelas. Jakarta: PT Bumi Aksara.

Arikunto, S. (2013). Prosedur Penelitian: Suatu Pendekatan Praktik. Jakarta: Rineka Cipta.

Baharuddin. 2008. Teori Belajar dan Pembelajaran. Yogyakarta: Ar-Ruzz Media.

Cholid Narbuko dan Abu Ahmadi, 2001, "Metode Penelitian", Bumi Aksara, Jakarta

Daryanto. (2014). Pendekatan Pembelajaran Saintifik Kurikulum 2013. Yogyakarta: Penerbit Gava Media.

Hamalik, O., (2011), Proses Belajar Mengajar. Jakarta: Bumi Aksara

Hermawan, Asep Herry. 2013. Pengembangan Kurikulum dan Pembelajaran. Jakarta: Universitas Terbuka

Huda, Miftahul. 2013. Model-model Pengajaran dan Pembelajaran. Yogyakarta: Pustaka Pelajar

Huda, Miftahul.2015. Model-Model Pengajaran dan Pembelajaran. Yogyakarta.Pustaka Pelajar

Malawi, Ibadullah \& Ani Kadarwati. 2017. Pembelajaran Tematik (Konsep Dan Aplikasi). Magetan: CV. AE Grafika

Moleong (1998), Metodologi Penelitian Kualitatif, CV. Remaja Rosdakarya, Bandung.

Kunandar. 2010. Pelaksanaan Pembelajaran. Bandung: PT Remaja Rosdakarya

Paizaluddin dan Ermalinda. (2016). Penelitian Tindakan Kelas (Classroom Action Research) Panduan Teoritis dan Praktis. Bandung: Alfabeta

Rusman. 2017. Belajar dan Pembelajaran Berorientasi Standar Proses Pendidikan. Jakarta: Kencana.

Sanjaya, Wina. 2016. Strategi Pembelajaran Berorientasi Standar Proses Pendidikan. Jakarta: Kencana

Shoimin, Aris. 2014. 68 Model Pembelajaran Inovatif dalam Kurikulum 2013. Yogyakarta: Ar-Ruzz Media.

Siregar, Evline dan Hartini Nara. 2011. Teori Belajar dn Pembelajaran. Bogor: Gahlia Indonesia.

Sugiyono. 2009. Metode Penelitian Kualitatif, Kuantitatif dan R\&D. Bandung: Alfabeta.

Sugiyono. 2013. Metode Penelitian Kualitatif, Kuantitatif dan R\&D. Bandung: Alfabeta.

Sugiyono. 2016. Metode Penelitian Kualitatif, Kuantitatif dan R\&D. Bandung: Alfabeta.

Sugiyono. 2018. Metode Penelitian Kualitatif, Kuantitatif dan R\&D. Bandung: Alfabeta.

Sukardi. 2013. Metode Penelitian Pendidikan : Kompetensi dan praktiknya. Jakarta: PT Bumi Aksara.

Suprijono, Agus. 2015. Model-Model Pembelajaran. Jakarta: Gramedia Pustaka Jaya.

Susanto, Ahmad. 2016. Teori Belajar dan Pembelajarani. Jakarta: Praneda Media Group

Syah, Muhibbin. 2011. Psikologi Pendidikan. Bandung: Remaja Rosdakarya.

Wardhani, IGAK. 2008. Penelitian Tindakan Kelas. Jakarta: Universitas Terbuka. 